\title{
Recollections on the \\ Centre for Reformation and Renaissance Studies, Victoria University in the University of Toronto (2004 to 2014)
}

\author{
KIMBERLEY YATES \\ University of Toronto \\ AMYROSE MCCUE GILL \\ Stanford University \\ NATALIE OELTJEN \\ University of Toronto
}

STEPHANIE TRELOAR

University of Toronto

LINDA GAIL STONE

University of Toronto

$\mathrm{T}$

he Centre for Reformation and Renaissance Studies (CRRS) at Victoria

College, Victoria University in the University of Toronto, celebrates its own fiftieth anniversary in 2014. ${ }^{1}$ From its origin as a library and locus for smallscale scholarly events, the CRRS has grown into an internationally-recognized research and teaching centre, attracting students and scholars of the early modern period from around the world. The CRRS library holds a collection of rare and modern books relating to virtually every aspect of the Renaissance and Reformation. In particular, the CRRS houses the Erasmus collection, one of the richest resources in North America for the study of works written or edited by the great Dutch humanist Desiderius Erasmus of Rotterdam (d. 1536).

The CRRS also supervises the undergraduate program in Renaissance Studies at Victoria College in the University of Toronto. It organizes academic events, including workshops, lectures, and colloquia, two special lecture series per year (the Erasmus lecture in the fall and the Distinguished Visiting Scholar lectures in the spring), a yearly concert featuring early modern music (the Bowen concert), and a yearly interdisciplinary and international conference. It publishes several academic book series in the field of Renaissance and Reformation studies: The Other Voice in Early Modern Europe, co-published

1. The first paragraphs of this profile are drawn from the CRRS website (www.crrs.ca).

Renaissance and Reformation / Renaissance et Réforme 37.3, Summer / été 2014 
with Iter: Gateway to the Middle Ages and Renaissance (Iter); Essays and Studies; Texts in Translation; and Tudor and Stuart.

The CRRS is administered by a Director and Associate Director from the University of Toronto with support from a full-time Assistant to the Director (A/D). The Centre also has a part-time Finance Assistant and-thanks to a long-standing practice of offering many fellowship, employment, and volunteer opportunities - graduate and undergraduate students who help at the front desk of the library and with the publications program as well as with event planning, promotion, and execution. The CRRS Director reports directly to the principal of Victoria College. In overseeing the work of the CRRS, the Director is advised by a small Executive Committee and a larger Managing Committee that meet throughout the year at the Director's discretion, as well as by a series of faculty committees linked to each of the Centre's primary activities: library collections, academic program, early modern events, and scholarly publications. The Centre also offers a fellowship program to scholars requiring use of the CRRS library collection and wishing to participate in the Centre's other activities. This programming is made possible in part through the generous financial support of dedicated philanthropists and through the many gifts of books and time the Centre receives from committed long-term contributors, including Stephanie Corbet, Konrad Eisenbichler, James Estes, Larry Pfaff, F. David Hoeniger, Olga Zorzi Pugliese, and Germaine Warkentin, to name only a few.

The Centre collaborates with the Renaissance Society of America (RSA) and the Sixteenth Century Society and Conference (SCSC) by participating actively in their annual meetings and, in the case of the RSA, by sending a representative to its Council meetings. In turn, the RSA awards two one-month paid fellowships at the Centre, one of which is reserved for art historians. Only the Huntington Library in San Marino, California and the Newberry Library in Chicago are similarly privileged with such a fellowship from the RSA. Longstanding relationships with international bodies are also to be found in the decades when the CRRS collaborated with the Fédération Internationale des Sociétés et Instituts pour l'Étude de la Renaissance (FISIER) and in the role that the CRRS has played as a founding member in the international partnership Iter.

The following recollections are from the five most recent Assistants to the Director, who were hired by the Centre for their administrative and scholarly expertise shortly after receiving their doctorates in Renaissance or Reformation 
studies. These memories of the Centre and its activities span slightly more than the last ten years; the earlier history of the CRRS is recorded in James M. Estes, The First Forty Years: A Brief History of the Centre for Reformation and Renaissance Studies 1964-2004 (CRRS, 2004). Many of the initiatives outlined below predate these A/Ds, and most have continued in one form or another to the present day. Each A/D's account stresses the major changes undergone at the Centre in one specific area of its activities during the period of her tenure: Kimberley Yates (English, A/D from 2002 to 2008) facilitated the major growth of CRRS Publications; Stephanie Treloar (Music History, A/D from 2008 to 2011) oversaw significant additions to the library and managed CRRS affairs during a time of changing leadership; Amyrose McCue Gill (Italian, A/D from 2011 to 2012), Linda Gail Stone (Art History, A/D from 2012 to 2013), and Natalie Oeltjen (Medieval Studies, A/D from 2013 to the present) designed, developed, and implemented outreach projects aimed at local, Canadian, and international scholars and students, both on campus and online. Their stories follow.

\title{
So many books: CRRS publications Kimberley Yates (A/D 2002-2008)
}

\begin{abstract}
A fter years of contract teaching and temporary administrative jobs, I was thrilled to gain a permanent position as Assistant to the Director at the CRRS. I was eager for growth and new experiences, and the CRRSthen directed by William R. Bowen (University of Toronto Scarborough and Faculty of Music) with Nicholas Terpstra (Department of History) as Associate Director-obliged me in full. In the period that followed, the Centre hosted the annual conferences of the RSA (2003) and the SCSC (2004); established a formal archive for the CRRS, Canadian Society for Renaissance Studies / Société canadienne d'études de la Renaissance (CSRS/SCÉR), and Toronto Renaissance and Reformation Colloquium (TRRC) through the efforts of Natalie Treboute; celebrated a fortieth anniversary and had our history written by James $M$. Estes; established new funds in honour of Germaine Warkentin and Konrad Eisenbichler; assumed responsibility for the academic administration of the undergraduate program in Renaissance Studies during a period of substantial growth and development guided by Terpstra; developed a proposal for a Collaborative Graduate Program in Early Modern Studies (2004) that revived
\end{abstract}


a long-standing wish to establish a graduate-level program in Renaissance Studies at the University of Toronto, an initiative that was first attempted by F. David Hoeniger in the early 1970s and then by Germaine Warkentin in the mid-1980s; played a substantial role in managing the graduate students employed by the Iter Fellowship program; acquired a number of significant rare books for the collection; and supported international research projects such as Le Groupe de recherche sur les entrées solennelles.

Our events list grew every year. Long-standing traditions included lectures co-sponsored with the TRRC as well as monthly Friday Workshops; a yearly Distinguished Visiting Scholar visit; an Erasmus Lecture; and an annual fall conference. In 2007 we saw the launch of the annual Renaissance Spring Festival and the William Bowen concert. All of these activities and events enabled the CRRS to connect with and help foster a community of scholars both local and international. A concerted recruiting effort brought colleagues from various departments and neighbouring universities (including Elizabeth "Libby" Cohen, Thomas V. Cohen, James Carley, Jane Couchman, Margaret Reeves, and Antonio Ricci, all of York University; Katherine Acheson and Ted McGee of the University of Waterloo; and Donald Beecher from Carleton University) onto CRRS committees. Some new members came from further afield and participated electronically in our committee meetings, like Margaret King of the City University of New York and Albert Rabil Jr. of the State University of New York (Old Westbury). Weekly lunch meetings of the Executive Committee were lively gatherings during which committee chairs could share ideas and discuss CRRS business, and newly-hired early modernists could be welcomed into the growing community. In 2007-08 alone, my final year at the Centre, we hosted forty-nine separate events that brought together nearly 2,400 participants.

During my years at the CRRS, the area that underwent the greatest change - and had the deepest impact on future operations - was the publications program. The CRRS hosted two journals (Early Theatre and Confraternitas) and was co-copyright holder of a third, Renaissance and Reformation/Renaissance et Réforme (R\&R). Bowen's strategy was to position the CRRS as the production manager of a number of journals, thereby providing the Centre with the income it would need to create a new position, that of Publications Assistant, to support the growing publications program. At the same time, CRRS was a partner in Iter; Iter Fellowships (for which Bowen negotiated funds from the University of Toronto) funded many graduate students who contributed to the 
online bibliography and produced an in-house newsletter. These projects remained fairly stable throughout my time, but in the area of published books the CRRS experienced amazing growth-it is here that I will tell my story.

In 2002, the Centre's publications program was small if purposeful, with the appearance of a volume every year or two. Our publications were focused on careful scholarship aimed at an audience of fellow researchers, and they sold slowly but regularly, mostly via mail orders. We were already home to two series of books, Tudor and Stuart Texts and Renaissance and Reformation Texts in Translation, when Eisenbichler created the series that quickly became the largest and most interdisciplinary, Essays and Studies. The first volume of this new series, The Premodern Teenager (2002), was a collection of essays that grew out of a successful two-day conference Eisenbichler had organized at Victoria College in 1999, a model that the series has continued to follow for its edited volumes to this day. The Premodern Teenager was the first to be adopted as a classroom textbook, and it justified its large initial print run by continuing to be a popular choice until the Centre finally ran out of stock. Subsequent volumes in the Essays and Studies series came quickly and appealed to an ever-larger audience of readers across the disciplines with interests in the nineteenth-century "discovery" of the Renaissance (2003), law (2004), deceit (2004), Ovid in the Renaissance (2004), and patronage (2005).

In 2004, Bowen entered into negotiations with another small Canadian publisher of scholarship on early modern topics, Dovehouse Press, which for years had been managed by Don Beecher of Carleton University and which had earlier served as a distributor of CRRS publications. As he approached retirement, Beecher found the logistics of storing, marketing, and shipping books to be an increasing challenge; he offered the Centre the opportunity to take on his inventory and remaining publishing commitments in exchange for a share in the profits. Bowen saw that Dovehouse was a good fit for CRRS, with a roster of texts in areas that the CRRS had not previously explored (especially drama). By taking over two Dovehouse series-Texts Published by the Barnabe Riche Society and Carleton Renaissance Plays in Translation-the CRRS suddenly tripled the size of its publications program. This brought many benefits, but it also posed some distinct challenges.

The first challenge CRRS had to meet was the sheer size of the Dovehouse inventory. There were hundreds of cartons of books, in both hardcover and softcover editions. We initially stored them in the attic of old Victoria College, 
but there were concerns about the impact of their weight on a 150 -year-old timber-frame building, so in the summer of 2006 the books were moved to a newly designated storage space in the parking garage of Rowell Jackman Hall. Unconventional? Yes-but the space was dry and it worked well.

To sell both the newer and original CRRS series, we reorganized our advertising sheets, order forms, sales files, and website. As orders arrived more quickly, the job of Publications Assistant Kelli Carr grew exponentially, but her resourcefulness, professionalism, and hard work kept pace and she made the impossible happen. With Kelli's in-house support, I began to attend conferences more frequently so that the CRRS would have a more regular book table presence and greater visibility for scholars in the field. At least twice each year, I organized the flight, hotel, registration, table, shipping, and volunteers, and took onsite orders. It was exhilarating and exhausting.

By the time I left the CRRS, in the summer of 2008, new books were being published at an increasingly rapid rate, and our catalogue offered nearly a hundred titles for purchase. In my last month, I contributed to the SSHRC applications for two of our three journals (R\&R and Early Theatre) and they were both successful. As I moved to assume another position at the university I wondered if the CRRS publications program had grown almost too fast; if the pace and scale would be hard to maintain. Yet, somehow it has kept going, like the bumblebee that's not supposed to be able to fly and yet remains aloft.

\section{Beyond publications: the CRRS library and leadership Stephanie Treloar (A/D 2008-2011)}

D uring my three-year tenure at the CRRS, publication activities continued to increase at a dizzying pace. The most significant new initiative at this time was the launch of The Other Voice in Early Modern Europe series. Coedited by Albert Rabil and Margaret King, The Other Voice offered English translations of significant works related to women and gender published in European languages during the early modern period. The University of Chicago Press had published over fifty-five volumes in the original "Chicago series" of The Other Voice when it decided that it no longer wished to continue. In 2007, Bowen had once again seen an opportunity to expand the Centre's scholarly reach and contribution; he negotiated an agreement with Rabil and King that would launch a new "Toronto series" of The Other Voice such that the most 
important venue for publication of works by women in the Renaissance and early modern period would be co-published by the CRRS and Iter. The new series was officially launched in 2009 with Journey of Five Capuchin Nuns, edited by Sarah Owens. Each book in the new Toronto series was published both in hard copy and electronically, marking a shift in CRRS publishing towards e-books that has since continued and grown. The addition of this prestigious series to the Centre's publications program has borne out an important part of Bowen's initial vision: publishing new editions of texts, many of which had lain forgotten and inaccessible for centuries, has enabled the CRRS to take advantage of a significant opportunity to aid scholarship by making otherwise silent voices speak to both students and scholars. Under the able leadership of the series editors, Other Voice publications came out with impressive speed: by June 2011, eleven volumes had already been released.

The costs of publishing ever-growing numbers of books required the steady income of book sales, so the quest continued to find better mechanisms for increasing the visibility and brand-name recognition of CRRS publications (now appearing in seven series) among scholars, students, and university libraries. Towards the end of 2010, the CRRS set up the infrastructure to begin selling its publications on Amazon.com and Amazon.ca. This proved a popular move, especially for books in The Other Voice series, and thus the publications program continued to grow, despite increasing pressures on its tiny staff, limitations of physical space, and the Centre's dedication to continue developing as a library and scholarly community.

With publications requiring still more attention, it might have been the case that other aspects of the CRRS were neglected-yet they were not. The library, for one, thrived. Between 2008 and 2011, several important new Erasmus-related acquisitions were made. The most notable of these was a first edition of the Aliquot Epistolae sane quam elegantes Erasmi Roterodami, the first collection of letters of Erasmus to be printed by Froben. The volume consisted of fifty-two letters written by Erasmus and his correspondents from 1514 to 1517, including the four letters to Leo X published by Froben in 1515; the collection of eighteen new letters published by Martens at Louvain in 1516; and the thirty-one new letters published, again by Martens, at Louvain in 1517. The volume also contained a dedicatory letter by Pieter Gillis and the letter of Adrianus Barlandus to his brother, Cornelius, in which the former gave an account of all of Erasmus's works to date. Correspondents represented in the 
volume included Wolfgang Faber Capito, Guillaume Budé, Wilhelm Kopp, Francis I, Ludovico Canossa, Thomas Gray, Pierre Vitré, Adrianus Barlandus, Pope Leo X, Ludwig Baer, Henricus Glareanus, Herman Busch, Johannes Sapidius, Cardinal Domenico Grimani, Henry VIII, Henry Bullock, Willibald Pirckheimer, John Colet, Jacques Lefevre d'Étaples, and Thomas More.

The edition, a large copy with generous margins and a beautiful, intricately carved title page border by Hans Holbein the Younger, was also quite rarethe Online Computer Library Center located only three other copies in North America (at the Folger, Grolier Club, and Yale). The CRRS already possessed a copy of the Auctarium selectarum aliquot epistolarum (Basel: Froben, 1518), a separate collection of Erasmus's letters published by Froben in the same year as the Aliquot epistolae. The two volumes together thus provided the CRRS library with a near-complete collection of the published letters of Erasmus to 1518.

Another interesting addition to the Erasmus holdings was a midsixteenth-century collection of pasquinades, compiled by Italian humanist Caelius Secundus Curio (1503-69). In addition to verse pasquinades of the fifteenth and sixteenth centuries, the volume contained more polished prose works including, most pertinently for the CRRS, Erasmus's unpublished satire of Julius II, Julius Exclusus e Coelis. Three more Froben editions of Erasmus's works were added to the CRRS collection during this time: a combined edition of the Ratio seu methodus compendio perveniendi ad uera $[\mathrm{m}]$ Theologiam along with Paraclesis, id est, exhortatio, ad studium Evangelicae philosophiae, per eundem (Nuremberg: Johann Petreius, 1523); the Exomologesis, sive modus Confitendi (Basileæ: ædibus Frobenianis, 1530); and the Divi Ioannis Chrysostomi Archiepiscopi Constantinopolitani commentarius in epistolam ad Galatas, Erasmo Roterodamo interprete. Opus novum, et nunc primum natum atque excusum (Basel: Johan Froben, 1527).

With the continued growth of both rare and modern collections at the library, it was decided that the ever-changing nature of information and the Centre's interest in establishing more direct lines of communication with its users demanded a more dynamic website-one that would bring the CRRS's online presence up to date and make more visible its activities and, of course, its library holdings. Designed by then CRRS webmaster Alexandra Guerson (now with the International Foundation Program, New College), the new site was intended above all to facilitate easy retrieval of increasingly copious and diverse information. In January 2010, in order to increase the profile of the CRRS's rare 
book holdings, the Centre began featuring online, every other month, a different rare book from its rich collection of early imprints. The CRRS Featured Rare Book segments, initiated by then CRRS Fellow Scott Schofield (now assistant professor at Huron University College, Western University), provided details on the authorship, contents, and print history of the work, as well as a discussion of the copy's binding, provenance, and features of note. Each entry began with a "book dealer"-style description and was accompanied by a series of digitized images with notes. This program was imagined as an interactive experiment: a place where users could not only examine copies from the Centre's rare holdings but also share their expertise, offer comments, and pose questions prompted by the descriptions and notes provided. Since the first Featured Rare Book segments were posted, other book historians have had the opportunity to learn from and contribute to both knowledge about and visibility of CRRS rare books, simultaneously honing their bibliographic skills and furnishing the Centre with a deeper understanding of its holdings. In 2011-12, for instance, John McQuillen (now assistant curator, Printed Books and Bindings, Morgan Library \& Museum) studied the incunabula and sixteenth-century German rares, providing the Centre with a preliminary catalogue of these previously understudied books.

Although the years 2008 to 2011 were a period of shifting leadership at the CRRS, the overall growth in activities and profile of the Centre was undiminished. Director Olga Zorzi Pugliese (Department of Italian) completed the final year of her directorship in 2008-09. During her four-year term the CRRS maintained its excellent reputation and developed and expanded its activities in several areas, notably in increased numbers of well-reviewed publications and in annual conferences attracting participants from around the world and attended by many the University of Toronto graduate and undergraduate students. Pugliese also cultivated and consolidated strong links with the broader community, including the Italian Cultural Institute and, with Eisenbichler, the Bata Shoe Museum. In this period the undergraduate program in Renaissance Studies-brought into the CRRS by Bowen in 2004 and overseen by Associate Director Nicholas Terpstra-also expanded steadily with new courses, a new Specialist (honours) stream, and an increasing number of students who were drawn into a newly-created Renaissance Students' Association. Pugliese and Terpstra also worked with Victoria College and many university departments on a collaborative graduate program in early modern studies that substantially 
revised and expanded a plan proposed by Bowen some years earlier. ${ }^{2}$ Such a program would see the CRRS take a co-ordinating role in a new suite of courses, workshops, and training seminars (language, paleography, digital humanities) that would bring together the University of Toronto's extraordinary faculty and library resources into a leading graduate-level initiative.

In the final year of Pugliese's term an extensive and very positive external review of the Centre inspired a wide-ranging search for its next leader. The search committee ultimately invited Lynne Magnusson (Department of English) to serve as Director. Due to pre-existing research commitments, however, she could not begin immediately; it was therefore necessary to appoint an Interim Director for the academic year 2009-10. Jane Couchman (French, Humanities and Women's Studies, Glendon College, York University), an early modernist who had been involved with the CRRS since the 1960s, served in this role through the transitional year, offering thoughtful leadership and consensusbuilding talents. More than just a steady hand on the tiller, Couchman continued the work begun in the previous decade of broadening and deepening the Centre's relationships with early modernists and other stakeholders (including early music performers!) at universities across southern Ontario.

When Magnusson arrived in office in July 2010, one of her first initiatives was to launch a yearly Celebration of Early Modern Studies, a one-day event consisting of panels dedicated to individual research by colleagues at the University of Toronto. This event was designed to provide faculty, postdoctoral fellows, and senior graduate students with an opportunity to talk about their research and to establish contacts across the rich, yet often all too dispersed, local early modern studies community. With similar goals in mind, she revamped the Friday Afternoon Seminars originally devised and energetically led by CRRS Curator Michael Milway (now teaching at Boston Trinity Academy) in the 1990s.

Under the guidance of the new Renaissance Studies Program (RSP) coordinator Manuela Scarci (Department of Italian Studies), the undergraduate Renaissance Students' Association continued to develop its presence on

2. The units involved included the Departments of Fine Art, French, German, History, Italian Studies, and Spanish \& Portuguese, the Centre for Comparative Literature, the Centre for the Study of Religion, the Graduate Centre for Study of Drama, and the Institute for the History and Philosophy of Science and Technology; the Faculty of Music also supported the proposal. Within Victoria University, the proposal was supported by the CRRS, the Renaissance Studies Program, and Victoria College itself. 
campus. It achieved status as a recognized campus organization, allowing it to access funding from the University of Toronto Arts and Science Student Union to sponsor both academic and social events. The association promoted Renaissance studies among fellow students through the widespread distribution of specially designed posters, the staffing of information booths during orientation week, the presentation of short program overviews to students in undergraduate classes, and the organization of academic and cultural activities related to Renaissance studies. Work paused on the Collaborative Graduate Program in Early Modern Studies to make room for these new priorities.

\section{Reaching out: the CRRS community of scholars and students Amyrose McCue Gill (A/D 2011-2012) Linda Gail Stone (A/D 2012-2013) Natalie Oeltjen (A/D 2013-)}

$\mathrm{I}^{\mathrm{s}}$

$\mathrm{n}$ recent years, changing times and changing personnel have brought new perspectives to bear on the Centre's traditional activities. The library has continued to grow as the CRRS acquired an excellent range of modern volumes that complemented the existing collections and, with the greatly appreciated guidance of Jim Estes and Konrad Eisenbichler, the CRRS purchased a number of significant rare items, including a copy of Erasmus's Catalogus novus omnium Lucubrationu[m] Erasmi Roterodami: cum censuris \& digestione singularum in suos tomos (Froben, 1524) which, paired with the 1523 edition of the text already in the CRRS collection, presents a significant opportunity for scholarly study.

CRRS Publications, in turn, has undergone significant restructuring during the tenure of Director Magnusson and Associate Director Ethan Matt Kavaler (Department of Fine Art). Two of the three journals previously managed by CRRS (Early Theatre and R\&R itself) have moved their administration elsewhere and the Dovehouse stock (still numbering in the thousands of volumes) has been sold to a remainder firm. The result of these two major developments has been to allow the CRRS to better manage its storage space, finances, and staff time; this, in turn, has enabled it to focus its energies on the Centre's Essays and Studies and Other Voice series. In 2013-14, The Other Voice saw its output increase to approximately one volume per month, such that the "back offices" located in the CRRS library have become an even more bustling 
hub of publication planning, post-press promotional activity, and order fulfilment. Vanessa McCarthy, Graduate Fellow in Publications and Promotions, and Karen Read, Administrative Assistant, Finance, with the help of several undergraduate assistants-whose work has been invaluable in this period-have done a tremendous job managing and marketing the increasing number of publications produced by the CRRS both alone and in collaboration with Iter.

While maintaining and building local scholarly discourse and relationships, the CRRS has also actively sought to bring scholars from far afield into the early modernist community. A long-time practice at the Centre via fellowship and visiting scholar programs, this tradition saw a new and exciting element introduced in November 2012 when the CRRS announced its partnership with the Renaissance Society of America, which is generously funding a new RSA-CRRS Visiting Fellowship for scholars in need of CRRS library resources. Even short-term, funded connections with the Centre have resulted in practical gains beyond that of infusing local scholarship with ideas from abroad and ensuring ample use of the library's unique resources: on a 2013 Eisenbichler Fellowship, for instance, Valentina Sebastiani, an expert on Erasmus and the publisher Froben, provided the CRRS with an updated catalogue of its holdings which, in conjunction with her other suggestions, will make the collection yet more visible and accessible to scholars abroad. ${ }^{3}$

As noted above, bringing prominent international scholars to campus as Erasmus Lecturers and Distinguished Visiting Scholars has been a practice of the Centre since its early days. Scholars invited to Toronto in these capacities have often been presented with and have generously accepted the opportunity to share their wisdom-about everything from teaching, research, and publication to practical career advice-with graduate students in a variety of disciplines at CRRS-sponsored events, and to speak at greater length, in prearranged one-on-one meetings, with advanced students whose fields align closely with that of the invited scholar. In 2013, for instance, Distinguished Visiting Scholar Bruce Ray Smith (English and Theatre, University of Southern California) held a workshop entitled "Doing Phenomenology: A Roundtable Discussion" for faculty and graduate students, affording them the opportunity for in-depth discussion of the critical issues being addressed in his research and eliciting much excitement and discourse among participants. The CRRS is 
grateful to these visitors for openhandedly participating in its project to bring together various constituencies of early modernists in diverse scholarly settings to foster productive interdisciplinary and faculty-student interactions.

Facilitating frequent interdisciplinary conversation among Toronto graduate students and their faculty advisors was launched in a new format in 2011 by Magnusson and then graduate student and CRRS Graduate Fellow (now assistant professor of English, University of Chicago) Timothy Harrison as the Early Modern Interdisciplinary Graduate Forum (EMIGF). The lively and fruitful monthly discussions of this group are based upon conference-style research presentations by two graduate students or post-doctoral scholars from different disciplines, and are moderated by a grad student or postdoc from a third discipline. In the interests of extending scholarly inquiry beyond the classroom for undergraduates in the field and of offering them an opportunity to present and receive feedback in a serious but collegial atmosphere, the CRRS offers competitive assistantships to undergraduate students, most often in their final years of a bachelor's degree. Named for donors Stephanie Corbet and Natalie Treboute-who have, for many years, generously funded yearly assistantships in order to expand the opportunities and horizons of undergraduates interested in Renaissance and Reformation studies-the Corbet and Treboute Assistants staff the Centre's front desk and prepare and share their independent research at EMIGF and, more recently, via the CRRS website. Many have gone on to graduate study in the field of early modern studies.

The CRRS has long worked to strengthen its connections to the undergraduate and graduate community by keeping students informed about and explicitly welcomed to CRRS and other early modern events. Instructors in the RSP and in departments like History have incorporated CRRS conferences and workshops into their undergraduate and graduate courses, and students are always drawn into conference organizing committees. The Centre has also worked closely with the Renaissance Students' Association to co-sponsor events, including lectures, film series, career and graduate study workshops, Renaissance-related events, and special receptions at which undergraduates can host and mingle with visiting scholars. The CRRS looks forward to supporting this group's initiative to plan an undergraduate conference in 2015.

As part of its teaching endeavours, the CRRS offers palaeography workshops to facilitate archival research to interested scholars and students, providing participants with the practical skills they need as they begin work on 
primary sources in the archives. The longest-running (since 2001) palaeography workshop the Centre sponsors is an intensive week-long series of classes by Eisenbichler that focus on reading early modern Italian hands and analyzing the paratext of early Italian books; occasionally, French and English scripts have been the focus of the summer workshop. Undergraduate and graduate students have been the primary focus of the Centre's pedagogical offerings, in particular through VIC $345 \mathrm{H}$, a Renaissance studies course offered by Victoria University in partnership with the CRRS library that enables students to work in depth with rare books from the Centre's collection. As a further instance of new outreach endeavours, in 2011 a class of local middle-schoolers was invited to spend an afternoon being guided through some of the more impressive rare books in residence at the CRRS. These young people were surprisingly knowledgeable about and engaged in this hands-on presentation. One hopes that unique opportunities such as this will encourage bibliophilia in the next generation of scholars.

Many of these outreach initiatives are, if not entirely, at least substantially dependent upon the Centre's online presence. In order to facilitate scholarly communication among early modernists on and off campus, the CRRS was an early adopter of the technologies of the digital age. Most recently, with the indispensable support of Pratt Library's Systems department and the assistance of many work-study undergraduate students brought on board for their visual and communication skills, the Centre began to provide new opportunities for community engagement through a streamlined website, complete with new social media tools, including an increased presence on Facebook and a new Twitter account; an electronic newsletter; more targeted and efficient use of contact lists; and sharper, more visually enticing email promotions of events and publications.

Perhaps the largest such initiative has been launched very shortly before the printing of this issue-largest in the sense that it involves a project "team" comprised of current and past iSchool graduate students as well as current and past CRRS Graduate Fellows. Using a Zotero group/library in the initial stages, the ultimate aim of this initiative is to develop a specialized CRRS rare book catalogue accessible through the Centre's website, with descriptions of each volume's paratext (such as dedications and marginalia), binding information, and, in the case of particularly rare or interesting volumes, links to images of marginalia. Via forums that invite comment from the international scholarly 
community as well as from the wealth of local talent in and around Toronto, this project seeks to create online what the CRRS has sought hard from its very beginning in 1964 to undertake: that is, to reach out to, and bring together in conversation and scholarly debate, an engaged and interactive society of early modernists.

\title{
A note in conclusion \\ Ethan Matt Kavaler, Interim Director, CRRS
}

\begin{abstract}
A Interim Director of the Centre for 2014-15, our fiftieth year, I am grate- ful to our Assistants to the Director, past and present, for sharing their recollections and helping to construct a collective memory of our institution. The Centre thrives both as a set of resources and as a locus for the interests and energies of our extremely productive and varied early modern community in Toronto- undergraduate and graduate students, administrators, and faculty.
\end{abstract}




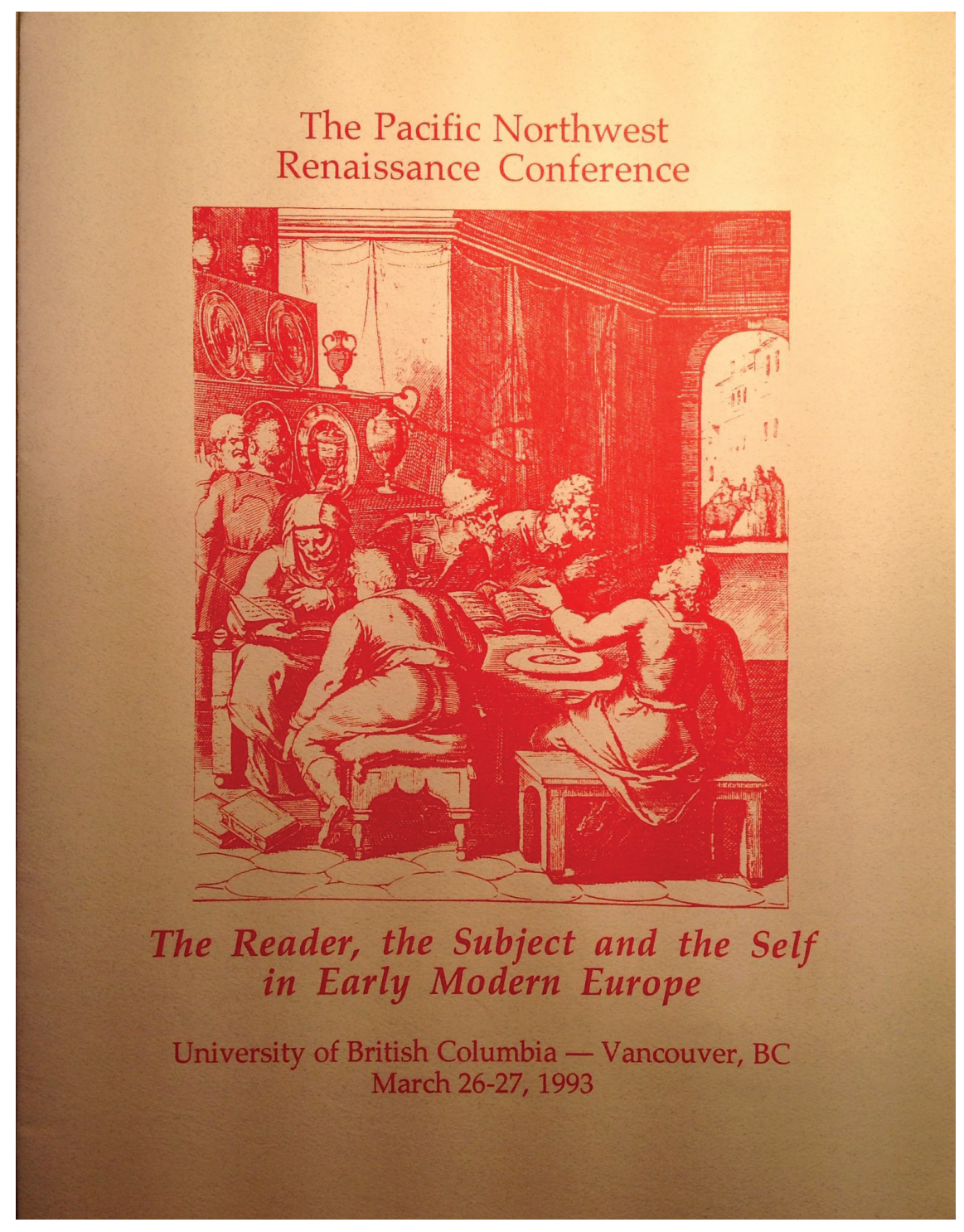

